\title{
Improving Formation Efficiency of Lead Acid Battery using Hydrogen Peroxide as an Additive
}

\author{
Senthil Kumar $\mathbf{P}^{1}$, Bhanu Prasad R ${ }^{2}$, Sumanth Vinay Kumar $\mathbf{B}^{3}$, Babu $\mathbf{N}^{4}$, Balaji $\mathbf{G}^{5}$, Jagadish $\mathbf{M}^{6}$ \\ Research and Engineering Centre, Amara Raja Batteries Limited, Tirupathi, Andhra Pradesh, India - 517520
}

\begin{abstract}
Formation is one of the critical step in lead acid battery manufacturing process. The purpose of formation process is to convert the cured paste into electrochemically active porous paste i.e. lead dioxide as positive plate and sponge lead as negative plate respectively. In the present work we studied " Improving formation efficiency of lead acid battery using hydrogen peroxide as an additive". This additive is oxidizing in nature. When this additive is subjected to high temperature or dissolved in water, it releases nascent oxygen. The nascent oxygen reacts with semi-conductive lead monoxide and converts it as conductive lead dioxide. The presence of lead dioxide in cured paste thus increases conductivity of plate and reduces the formation energy required for conversion during formation. So, to establish the impact of this additive on lead dioxide conversion and formation energy, samples made with and without addition of hydrogen peroxide. From XRD analysis, conversion of formed paste and formed cell discharge capacity test, it was observed that this additive can reduce the formation energy potentially up to $20 \%$.
\end{abstract}

Keywords: lead acid batteries, paste additive, oxidizing additive, formation efficiency, formation energy

\section{Introduction}

The process of formation can be conducted based on two basic methods namely, tank formation and container formation. In the earlier case, cured positive and negative plates are formed in large electrolytic tanks containing $\mathrm{H}_{2} \mathrm{SO}_{4}$ of $1.08-1.10$ relative density and then plates are assembled. Whereas in case of container formation, cured positive and negative plates are assembled into groups along with separator, which are then placed into the battery container and subjected to formation after filling with $\mathrm{H}_{2} \mathrm{SO}_{4}$ [1-2]. In both the methods of formation processes conversion of positive plates consumes more time and energy than negative plates. Oxidation of bivalent lead compounds in the paste and formation of the lead dioxide positive active mass passes through a number of chemical reactions, some of which proceed at a low rate, which retards the technological process of formation of the positive plate. In an attempt to accelerate the formation process, various studies had been carried out to improve the rate of conversion of lead dioxide and to reduce the formation energy. Earlier studies include two shot formation in container formation process, acid recirculation formation process, pulse charging and paste additives which includes conductive, porous and electrolyte additives.

Generally two formation methods are applied in container formation, two shot and single shot formation. In the two shot formation, the battery is filled with $\mathrm{H}_{2} \mathrm{SO}_{4}$ of relative density 1.08-1.15, after completion of formation the electrolyte is replaced with higher relative density $\mathrm{H}_{2} \mathrm{SO}_{4}$ to achieve the required relative density this is the one of the efficient process to reduce the formation energy and formation cycle time [1-3]

The $0.2 \mathrm{wt} \%$ (Silica gel) of material addition resulted in improved capacity at both low and high rates. Althoughthe addition of silica gel was not observed to cause significant physiochemical changes to the positive active-material; it is possible that silica gel promotes nucleation which consequently leads to a finer pore structure in the active material. Since this form of silica is porous, the additive may act as an acid reservoir [4].

Acid recirculation formation process is the one of the solution for the formation of Flooded Automotive and Industrial batteries. The process permits to maintain the constant temperature all over the plates inside the batteries, highly reducing the cycle time and increasing the quality of the formation process [5].

Different conductive additives for positive plates to improve the formation efficiency includes Barium plumbate, Titanium oxide, Tin dioxide, Lead dioxide, Carbon and Conductive Polymers were studied [1]. D Pavlov studied the effect of read lead as a conductive additive to improve the formation efficiency [2]. K.R Bullock et al investigated the ozone treatment that enhances conductivity of positive material [6].

The patent - US 2,658,097 A, manufacture of positive plates for lead storage batteries issued Nov. 3, 1953 mentioned that The oxidizing solution may be applied to the positive plates by immersing the plates in the solution or by applying the solution by dipping, painting, spraying or other known method. We have found it convenient to immerse the plates in the solution for an interval of time sufficient to form a thin deposit of higher oxides of lead on the surface of the active material in the positive plates. [7].

The patent - US 4909955 A, Lead oxide paste mix for battery grids and method of preparation issued on 20 Mar 1990 mentioned that, battery grades of oxides of lead are mixed with a dilute solution of hydrogen peroxide, either alone or with additives and/or expanders. The resultant paste offers such advantages as reduced curing and drying times and/or the elimination of the need for curing and drying, lower dry active material weights and improved cohesion when compared to conventional pastes manufactured from leady oxides, sulfuric acid, and water [10]. 


\section{International Journal of Science and Research (IJSR) \\ ISSN (Online): 2319-7064}

Index Copernicus Value (2015): 78.96 | Impact Factor (2015): 6.391

The patent - US 5149606 A, method of treating battery electrode with per-sulfate issued on 22 September 1992, discloses that, Improved formation efficiencies for positive pasted plates used in lead-acid batteries are provided by treatment of the positive plates with a stabilized aqueous alkaline persulfate solution to effect the conversion of lead monoxide to lead dioxide. Use of the alkaline persulfate solution enhances both formation and initial performance of the fabricated batteries [8].

Pulse charging option is available for the formation, it is used together with constant voltage/current profiles to increase charge acceptance, improve the charging time and to potentially increase the life cycle of lead acids cells [9].

In the present study we focused mainly on oxidizing additive to reduce the formation energy, by mixing the additive with paste. The effect was studied after curing, drying and formation. The concept of using additive to improve formation efficiency has been explored as it is easy to adopt in manufacturing and economical.

\section{Experimental}

$4.5 " \times 2.5 " \times 0.5 "(\mathrm{H} \times \mathrm{W} \times \mathrm{T}) \mathrm{Ca}-\mathrm{Sn}$ alloy based gravity casted grid was chosen for experimentation. Experiments were conducted with different percentages of additive as shown in the Table 2 with respect to the weight of leady oxide. Hydrogen peroxide is chosen as an additive for experimentation, it was added during paste mixing in positive active material considering the available active oxygen in it. Here onwards hydrogen peroxide and active oxygen are denoted as HP and AO respectively.

\subsection{Material properties}

HP is a colorless free flowing liquid, slightly viscous than water. It is an oxidizing agent with solid source of AO. It is readily soluble in water and can easily decompose at elevated temperatures thus releases nascent oxygen. Physical and chemical properties of HP are described in the Table 1 [10].

\subsubsection{Physical and chemical properties}

Table 1: Physical and chemical properties

\begin{tabular}{|c|c|c|c|}
\hline S. No & Property & UOM & $\begin{array}{c}50 \% \mathrm{H}_{2} \mathrm{O}_{2} \\
\left(50 \% \mathrm{H}_{2} \mathrm{O}+50 \% \mathrm{H}_{2} \mathrm{O}_{2}\right)\end{array}$ \\
\hline 1 & Molecular weight & $\mathrm{g} / \mathrm{mole}$ & 34.01 \\
\hline 2 & Appearance & - & Free flowing liquid \\
\hline 3 & Water solubility $@ 25^{0} \mathrm{C}$ & $\mathrm{g} / 1$ & Miscible \\
\hline 4 & Density & $\mathrm{g} / \mathrm{ml}$ & 1.20 \\
\hline 5 & Active oxygen & $\%$ & 23.54 \\
\hline 6 & $\mathrm{pH}$ & - & $<3$ \\
\hline
\end{tabular}

\subsubsection{Chemical Structure}

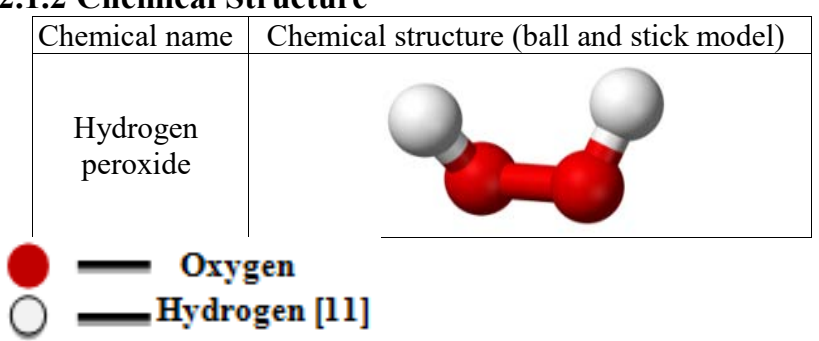

\subsection{Mechanism of HP}

HP is a strong oxidizing agent with high percentage of active oxygen. But when it is dissolved in water or exposed to elevated temperatures, nascent oxygen gets evolved. This nascent oxygen has the potential to react with leady oxide in such a manner that both residual lead and lead monoxide in the leady oxide will get oxidized.The following reactions are expected to occur and to establish the below reactions experiment detailed in section 2.3.1 has been carried out [12].

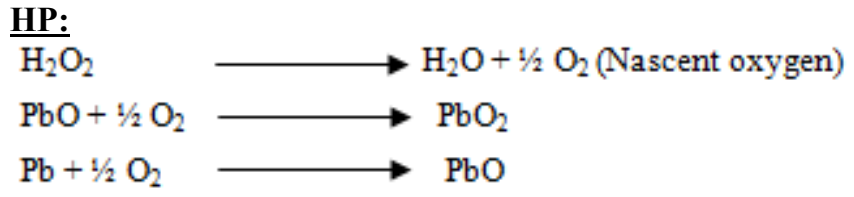

\subsection{Experimental procedure}

\subsubsection{Leady oxide mixing with HP}

To verify the above mechanism $5 \mathrm{~g}$ of laboratory reagent grade $\mathrm{HP}\left(50 \% \mathrm{H}_{2} \mathrm{O}\right.$ and $\left.50 \% \mathrm{H}_{2} \mathrm{O}_{2}\right)$ is slowly (drop by drop) mixed with $50 \mathrm{~g}$ of Barton mill leady oxide in the laboratory with continuous stirring at room temperature for 15 minutes, followed by $20 \mathrm{hrs}$ drying at $60^{\circ} \mathrm{C}$ and analysis was carried out to confirm the above mechanism. The results are discussed in 3.1 .

\subsubsection{HP as an additive in paste}

To study the effect of HP as an additive in paste mixing, curing and drying and formation, positive plates were prepared in the laboratory by mixing with different percentages of $\mathrm{HP}\left(50 \% \mathrm{H}_{2} \mathrm{O}\right.$ and $\left.50 \% \mathrm{H}_{2} \mathrm{O}_{2}\right)$ as stated in the Table 2 in paste mixing. Samples were made by the below procedure. The results are discussed in 3.2 and 3.3.

Table 2: Hydrogen peroxide addition with respect to leady

\begin{tabular}{|c|c|}
\hline \multicolumn{2}{|c|}{ oxide } \\
\hline Sample (50\%HP) & Leady oxide $(\mathrm{g})$ \\
\hline No additive (NA) & 1000 \\
\hline $1.07 \mathrm{~g}(0.3 \mathrm{~g} \mathrm{AO})$ & 1000 \\
\hline $2.14 \mathrm{~g}(0.6 \mathrm{~g} \mathrm{AO})$ & 1000 \\
\hline $5 \mathrm{~g}(1.17 \mathrm{~g} \mathrm{AO})$ & 50 \\
\hline
\end{tabular}

\subsubsection{Preparation of positive paste and plate}

Positive paste was prepared by using Barton mill leady oxide (with 22-28 wt. \% residual lead). Binder (poly ethylene terephthalate) was mixed with leady oxide and HP solution was introduced slowly into the leady oxide with different percentages as specified in Table 2 with good dispersion over the paste and mixing is carried out for 3 minutes. After mixing, water added as quickly as possible and uniformly mixed (wet mixing) for 3 minutes. After completion of wet mix, sulfuric acid (1.40 relative density) of battery grade was added to the mix in such a way that maintaining mix temperature below $60^{\circ} \mathrm{C}$ to form a specific paste morphology i.e., tri basic lead sulfates. Final mix was done for 3 minutes followed by the measurement of paste density.

Paste densities were adjusted to $4.20 \mathrm{~g} \mathrm{~cm}^{-3}$. Required quantity of paste weighed in a micro balance and manually 


\section{International Journal of Science and Research (IJSR) \\ ISSN (Online): 2319-7064 \\ Index Copernicus Value (2015): 78.96 | Impact Factor (2015): 6.391}

pasted on grid panelwhich is mentioned above. After pasting, panel was weighed and loaded into curing and drying oven. Plates were cured at $50^{\circ} \mathrm{C}$ by maintaining $95 \%$ relative humidity for 48 hours and dried at $60^{\circ} \mathrm{C}$ for 24 hours and plates were assembled in a commercial AGM battery case to form a dry unformed battery.

\subsubsection{Cell formation}

Required amount of chilled sulphuric acid $\left(<15^{\circ} \mathrm{C}\right)$ with 1.290 relative density was filled into the dry unformed battery using vacuum filling. After soaking the plates in electrolyte for $1 \mathrm{hr}$, charging was conducted. Connecting cables were connected to the battery in series and then allowed for charging using constant current charging process with water circulation to control the temperature during formation. The Ah input during formation has been varied between 5 to 6 times of its designed rated capacity of the cell in order to evaluate the effect of additive on reduction in input formation energy and improve in conversion efficiency.

\subsection{Analysis}

Leady oxide without and with HP as explained in 2.3.1, was analyzed by dissolution and precipitation method and XRD.

Positive cured paste without and with HP (1.07 g and 2.14 g) was analyzed by XRD and SEM. Positive formed paste without and with HP was analyzed for lead dioxide content by dissolution and precipitation method and for initial capacity at $10 \mathrm{~h}$ rate.

\subsubsection{Analysis of residual lead and lead dioxide content}

\subsubsection{Residual lead content in leady oxide after mixing with HP}

$5 \mathrm{~g}$ of leady oxide without and with HP was dissolved in 5\% acetic acid solution. Lead monoxide can effectively dissolve in acetic acid solution and the residual lead gets precipitated at the bottom; it is filtered, dried and weighed.

\subsubsection{Analysis of lead dioxide content in formed paste}

The positive formed paste contains lead dioxide, lead sulfate and lead monoxide. Lead dioxide content in formed paste was determined by the following methodology.

$5 \mathrm{~g}$ of positive formed paste was dissolved in $20 \%$ ammonium acetate solution. Lead sulfate and lead monoxide can effectively dissolved in this solution and lead dioxide gets precipitated at the bottom; it is filtered, dried and weighed.

\subsubsection{XRD analysis (X-Ray Diffractometer)}

The analysis of phase composition of the leady oxide and positive cured paste without and with HP was determined by using X-raydiffractometry. Samples collected after curing and drying was grinded into a fine powder and placed into a standard aluminum glass-slide-back sample holder. RIGAKU ULTIMA-IV X-Ray diffractometer was used with $\mathrm{Cu} \mathrm{K} \alpha$ radiation. Scans were conducted in the $2 \theta$ range of $10-90^{\circ}$, with a scan time of 4 deg. $\mathrm{min}^{-1}$. Different phase compositions (3BS, $\mathrm{PbO}, \mathrm{Pb}$ and $\mathrm{PbO}_{2}$ ) were analyzed and they are explained in 3.1.2 and 3.2.1.

\subsubsection{Paste morphology}

The analysis of paste morphology of positive cured paste without and with HP was determined by scanning electron microscopy (SEM). All samples were sputter coated with a thin layer of platinum, $\sim 5 \mathrm{~nm}$ in thickness, to reduce charging and improve image quality. Examination was carried out in a JEOL JSM-6010PLUS low vacuum model SEM using a working distance of $12 \mathrm{~mm}$, a spot size of 30 , and an electron beam voltage of $10 \mathrm{kV}$.

\subsubsection{Formed cell discharge capacity test}

Initial capacity tests were performed on formed cell in which positive formed paste made with, without and with HP. Tests carried out at $10 \mathrm{~h}$ rate current by BITRODE LCN CIRCUIT, USA. The initial capacity test results are given in Table 5.

\section{Results and Discussion}

\subsection{Leady oxide mixing with HP}

\subsubsection{Residual lead after mixing}

Residual lead percentage in leady oxide before and after mixing with HP $(50 \%$ HP) was shown in Table 3 . From the results reduction of $3.4 \%$ (average) of residual lead was observed after mixing with HP followed by drying. This indicates that, when leady oxide is mixed with HP, the residual lead gets partially oxidized to lead monoxide this results in residual lead reduction. This is in line with the earlier investigation of X.L. Wang et al [12]. Since, the effect of HP on oxidation of residual lead was already investigated (by X.L Wang et al), further experimentation was not detailed here.

Table 3: Oxidation of residual lead after treating with 50\%

\begin{tabular}{|c|c|c|c|}
\multicolumn{4}{|c}{ HP } \\
\hline \multirow{2}{*}{ Sample } & \multirow{2}{*}{ Leady oxide $(\mathrm{g})$} & \multicolumn{2}{|c|}{ Residual lead (wt. \%) } \\
\cline { 3 - 4 } & & Before mixing & After mixing \\
\hline \multirow{3}{*}{5 g of $50 \% \mathrm{HP}$} & \multirow{3}{*}{50} & 26.6 & 22.8 \\
\cline { 3 - 4 } & & 25.3 & 21.3 \\
\cline { 3 - 4 } & & 27.2 & 24.2 \\
\cline { 3 - 4 } & & 19.4 & 16.5 \\
\hline
\end{tabular}

\subsubsection{Lead dioxide after mixing}

XRD analysis was carried out on leady oxide without and with HP for lead dioxide peaks. Results were shown in Fig. 1 and Fig. 2. From the results, the additional lead dioxide peaks were observed when leady oxide mixed with HP and here $\lambda, \phi$ and $\Theta$ are the lead monoxide, residual lead and lead dioxide respectively. 


\section{International Journal of Science and Research (IJSR)}

ISSN (Online): 2319-7064

Index Copernicus Value (2015): 78.96 | Impact Factor (2015): 6.391

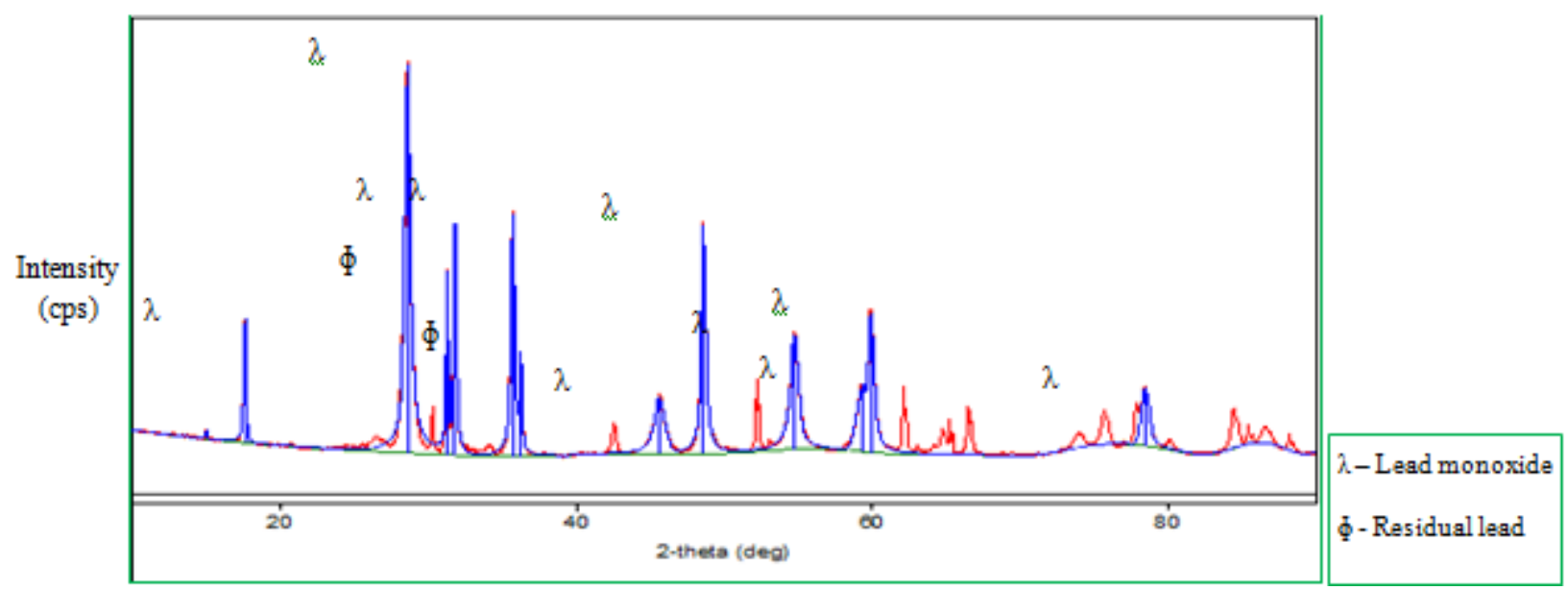

Figure 1: Leady oxide without HP addition

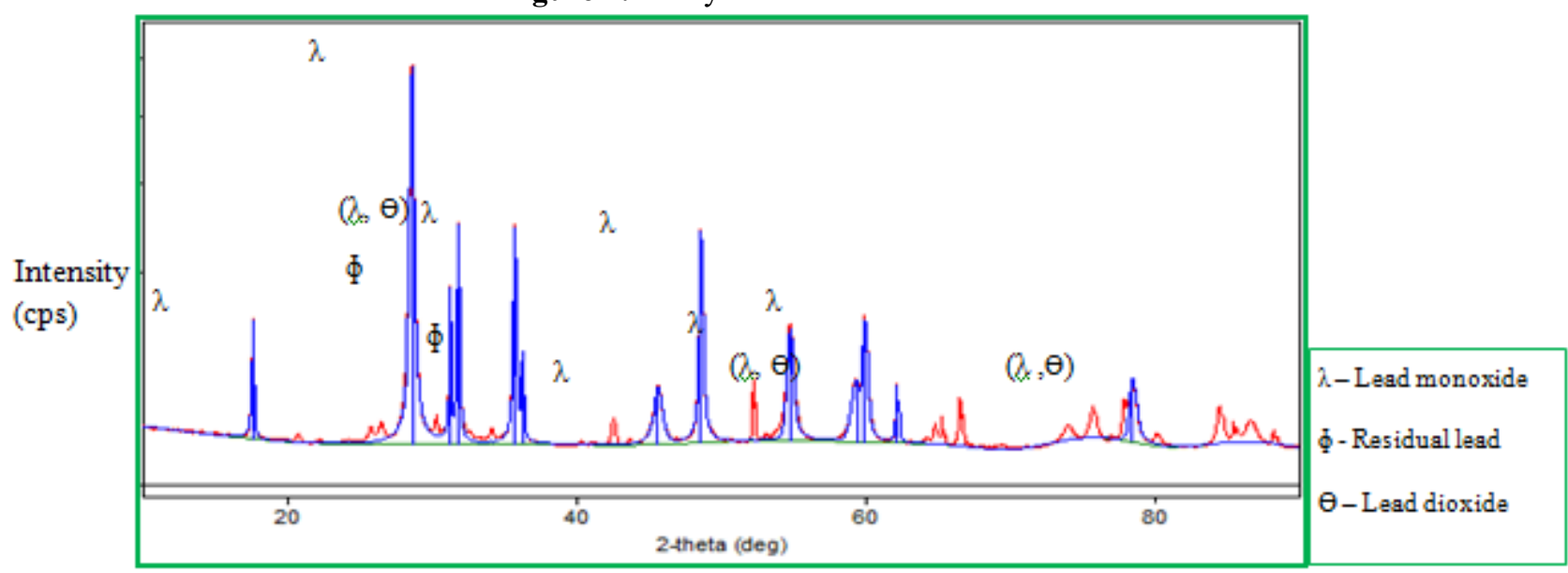

Figure 2: Leady oxide with HP addition

From the above XRD results, when leady oxide is mixed with HP, there is a slight reduction in residual lead percentage and at the same time lead dioxide phases were observed at $2 \Theta$ of $34.18,59.28$ and 77.82 degrees. So, the mechanism explained in 2.2 is expected to occur in this particular additive.

\subsection{HP as an additive in paste}

\subsubsection{XRD analysis}

XRD analysis of positive cured paste without and with HP was carried out to check the reaction of HP in curing and drying and for lead dioxide peaks. Results were shown in Fig. 3, 4 and 5. The characteristic lines of the substances are: tri basic lead sulfate, lead monoxide and lead dioxide. They are denoted by $\gamma, \lambda$ and $\Theta$ respectively. So, in positive cured paste with HP, lead dioxide peaks were observed at $2 \theta$ of $30.28,45.63,56.95,59.92$ and 77.86 degrees, after paste mixing, curing and drying process i.e., lead monoxide converts into lead dioxide due to availability of AO in the additive, as explained in chapter 2.2 Mechanism of HP.

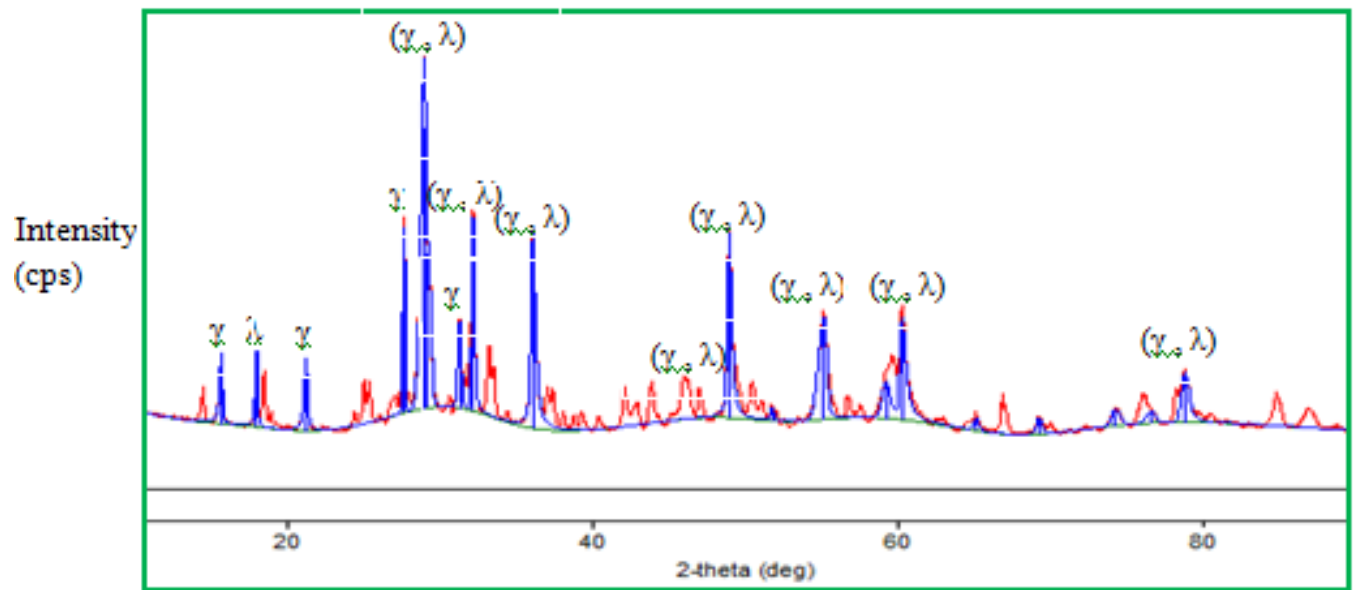

$\lambda$-Lead monoxide $\gamma-3 B S$

Figure 3: Without HP addition 


\section{International Journal of Science and Research (IJSR) \\ ISSN (Online): 2319-7064}

Index Copernicus Value (2015): 78.96 | Impact Factor (2015): 6.391

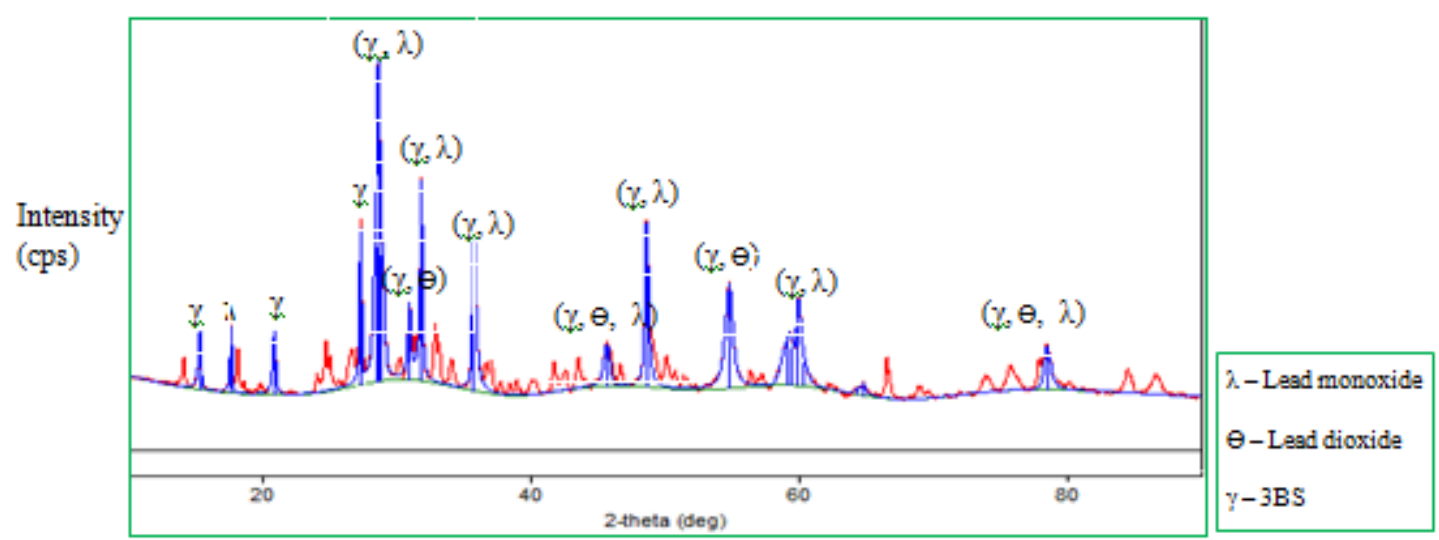

Figure 4: $1.07 \mathrm{~g} \mathrm{HP}$ addition

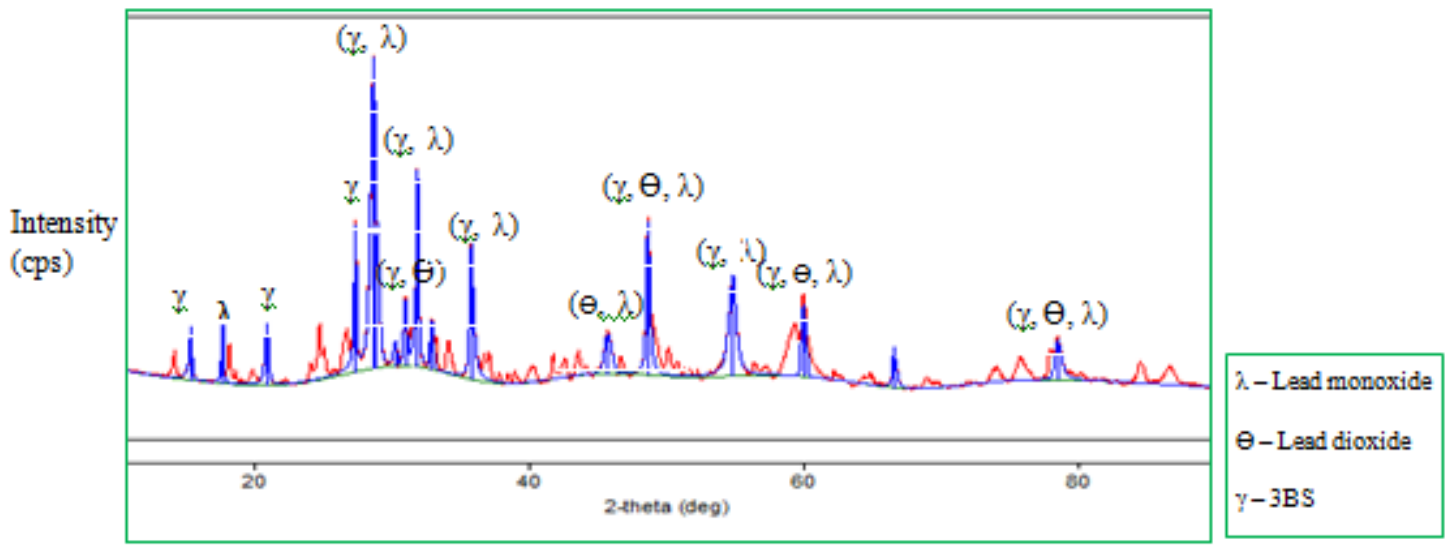

Figure 5: $2.14 \mathrm{~g}$ HP addition

Due to the addition of small amount of HP lead dioxide peaks were observed in low intensity with lead monoxide peaks. Lead dioxide presence is evident from XRD analysis. This lead dioxide in the positive cured paste increases the conductivity during the formation process there by formation efficiency increased and formation energy reduced.

\subsubsection{Paste morphology}

Scanning electron micrographs of positive cured paste without and with HP was carried out to check the paste morphology. Results were shown in Fig. 6. In both cured pastes lead monoxide agglomerates and cylindrical lead sulfate crystals were observed. Predominantly 3BS crystals were observed in positive cured paste without and with HP. From 3.2.1, in positive cured paste without and with HP, majority of the phases were $3 \mathrm{BS}$ and lead monoxide. This supports the cured paste micrographs.

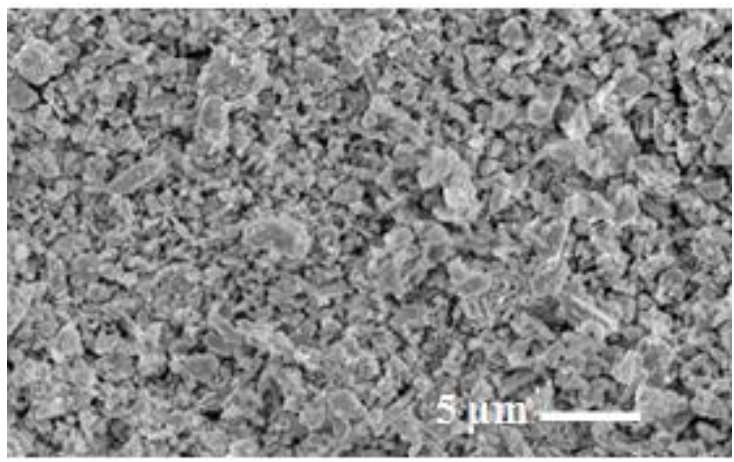

(a) Without HP addition

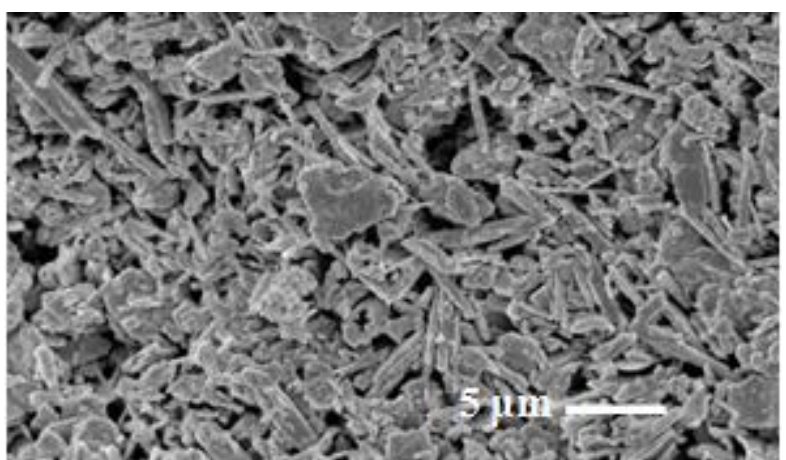

(b) $\quad 1.07 \mathrm{~g} \mathrm{HP}$ addition

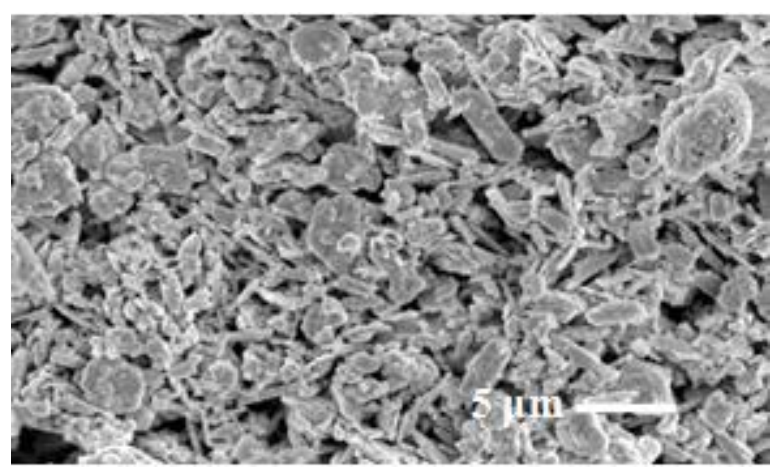

(c) $\quad 2.14 \mathrm{~g} \mathrm{HP}$ addition

Figure 6: Scanning Electron Microscope of cured paste with and without HP addition 


\section{International Journal of Science and Research (IJSR) \\ ISSN (Online): 2319-7064}

Index Copernicus Value (2015): 78.96 | Impact Factor (2015): 6.391

\subsection{Chemical analysis of formed paste}

\subsubsection{Lead dioxide conversion level and Formation} energy:

The conversion level of positive formed paste without and with HP obtained from different formation energies were shown in Table 4. In Table 4 all the samples were made with different formation input energies such as 5, 5.5 and 6 times the rated capacity and minimum required level of lead dioxide conversion is above $75 \%$.

Adequate conversion of lead dioxide for positive formed paste without HP was achieved at 6 times rated capacity of formation input energy, whereas in $1.07 \mathrm{~g} \mathrm{HP}$ paste required level of conversion is achieved in between 5-5.5 times of rated capacity of formation input energy and in $2.14 \mathrm{~g} \mathrm{HP}$ paste at 5 times of rated capacity, required level of conversion is achieved. Thus, by the addition of this additive in positive paste during paste mixing, $20 \%$ of formation input energy can be reduced during formation.

Table 4: Lead dioxide content in formed paste

\begin{tabular}{|c|c|c|}
\hline \multirow{2}{*}{ Sample } & $\begin{array}{c}\text { Input formation energy } \\
\text { in rated capacity }\end{array}$ & Composition (wt. \%) \\
\cline { 2 - 3 } & 5 & $\mathrm{PbO}_{2}$ \\
\hline \multirow{3}{*}{ NA } & 5.5 & 70 \\
\cline { 2 - 3 } & 6 & 73 \\
\hline \multirow{2}{*}{$\begin{array}{c}\text { 1.07 g HP } \\
(0.3 \mathrm{~g} \mathrm{AO})\end{array}$} & 5 & 76 \\
\cline { 2 - 3 } & 5.5 & 75 \\
\hline \multirow{2}{*}{$\begin{array}{c}2.14 \mathrm{~g} \mathrm{HP} \\
(0.6 \mathrm{~g} \mathrm{AO})\end{array}$} & 6 & 78 \\
\cline { 2 - 3 } & 5 & 82 \\
\cline { 2 - 3 } & 5.5 & 78 \\
\hline
\end{tabular}

\subsubsection{Rate of conversion with formation energy}

Rate of conversion of lead dioxide with formation input energy were shown in the Table 4 . In positive formed paste without HP, conversion of lead dioxide at 5, 5.5 and 6 times rated capacity of formation input energy is $70 \%, 73 \%$ and $76 \%$ respectively. Rate of conversion from 5 to 5.5 times rated capacity of formation input energy is increased by $3 \%$ and from 5.5 to 6 times rated capacity of formation input energy, it is increased by $3 \%$. So, rate of conversion is more or less same as formation input energy is increasing.

In positive formed paste with HP (1.07 g), conversion of lead dioxide at 5, 5.5 and 6 times rated capacity of formation input energy is $75 \%, 78 \%$ and $82 \%$ respectively. Rate of conversion from 5 to 5.5 times rated capacity of formation input energy is increased by $3 \%$ and from 5.5 to 6 times rated capacity of formation input energy, rate is increased by $4 \%$. So, rate of conversion is more or less same for $1.07 \mathrm{~g}$ HP paste. However comparing positive formed paste without HP and $1.07 \mathrm{~g}$ HP paste, conversion rate is about 5$6 \%$ higher in $1.07 \mathrm{~g} \mathrm{HP}$ paste. This indicates the presence of lead dioxide in cured paste accelerates the formation process.

In positive formed paste with HP $(2.14 \mathrm{~g})$, conversion of lead dioxide at 5, 5.5 and 6 times rated capacity of formation input energy is $78 \%, 83 \%$ and $85 \%$ respectively. Rate of conversion from 5 to 5.5 times rated capacity of formation input energy is increased by $5 \%$ and from 5.5 to 6 times rated capacity of formation input energy, rate is increased by $2 \%$. So, the rate of conversion in $2.14 \mathrm{~g}$ HP paste is slowly decreasing as formation input energy is increasing. This could be due to that, in $2.14 \mathrm{~g}$ HP paste the lead dioxide conversion has reached a maximum level. Similarly comparing $1.07 \mathrm{~g} \mathrm{HP}$ paste with $2.14 \mathrm{~g}$ HP paste, conversion rate is about $3-5 \%$ higher in $2.14 \mathrm{~g} \mathrm{HP}$ paste.

This indicates that the addition of HP and the resultant lead dioxide availability in the cured paste increases the rate of conversion of positive paste. Also, formation rate increases with increased addition of HP. The initial capacity test results are explained in the following paragraphs to supplement the lead dioxide conversion results.

\subsection{Formed cell capacity testing}

Initial capacity test results of formed cell, in which positive formed paste is made without and with HP, were shown in Table 5. The required level of delivered capacity is greater than or equal to $100 \%$.

In positive formed paste without HP, the capacity delivered at 5.5 times rated capacity of formation input energy is $103 \%$. Whereas in $1.07 \mathrm{~g}$ HP paste, it is $105 \%$ and in $2.14 \mathrm{~g}$ HP paste is $109 \%$. This is in corroboration with lead dioxide conversion level discussed in 3.3.2.

Comparing, $1.07 \mathrm{~g}$ HP paste at 5, 5.5 and 6 times rated capacity of formation input energy, delivered capacity is about $7-8 \%$ higher than positive formed paste without HP. Whereas in $2.14 \mathrm{~g}$ HP paste it is about $3-7 \%$ higher than $1.07 \mathrm{~g} \mathrm{HP}$. This data describes the mechanism explained in 2.2 i.e., during paste mixing, curing and drying lead monoxide reacts with HP gets oxidized to lead dioxide. The lead dioxide presence in the cured paste increases the conductivity and accelerates the formation process. So, paste with HP can improve the formation efficiency by reducing the formation input energy by $20 \%$.

Table 5: Cell initial capacity (at $\mathrm{C} 10$ rate)

\begin{tabular}{|l|c|c|}
\hline Sample & $\begin{array}{c}\text { Input formation energy in } \\
\text { rated capacity }\end{array}$ & Delivered capacity (\%) \\
\hline \multirow{2}{*}{$\begin{array}{l}\text { No additive } \\
\text { (NA) }\end{array}$} & 5 & 98 \\
\cline { 2 - 3 } & 5.5 & 103 \\
\cline { 2 - 3 } & 6 & 107 \\
\hline $\begin{array}{l}1.07 \mathrm{~g} \mathrm{HP} \\
(0.3 \mathrm{~g} \mathrm{AO})\end{array}$ & 5 & 105 \\
\cline { 2 - 3 } & 5.5 & 110 \\
\hline \multirow{2}{*}{$\begin{array}{l}2.14 \mathrm{~g} \mathrm{HP} \\
(0.6 \mathrm{~g} \mathrm{AO})\end{array}$} & 6 & 115 \\
\cline { 2 - 3 } & 5 & 109 \\
\cline { 2 - 3 } & 5.5 & 117 \\
\hline
\end{tabular}

\section{Conclusion}

The following are the main observations from the present study:

- The use of HP can convert the residual lead to lead monoxide during paste mixing [12].

- The addition of HP in positive active material during paste mixing and subsequent curing and drying process leads to the creation of small amount of lead dioxide. This was evident from XRD analysis. 


\section{International Journal of Science and Research (IJSR) \\ ISSN (Online): 2319-7064 \\ Index Copernicus Value (2015): 78.96 | Impact Factor (2015): 6.391}

- The conductive lead dioxide present in the cured paste potentially increases the conductivity of the paste during formation, thus enables the paste to form with less formation input energy compared to without additive sample

- $2.14 \mathrm{~g}$ HP was shown the higher impact on lead dioxide conversion at all levels of formation input energy and adequate conversion is achieved at 5 times rated capacity of formation inputenergy.

- Potentially up to $20 \%$ of formation input energy can be reduced by the addition of $2.14 \mathrm{~g} \mathrm{HP}$.

- The other impact of this additive in lead acid battery performance need to be further studied.

\section{References}

[1] D.A.J Rand, P.T. Moseley, J.Garche, C.D Parker, Valve regulated Lead acid batteries

[2] Detchko Pavlov Lead-Acid batteries science and technology

[3] An Exploratory Study on Electrolyte Circulation as a Means of Achieving Faster Formation of Lead Acid Batteries P. Senthil Kumar, K.S.N. Murthy*, K. Sudarsanam and S. Vijayanand

[4] K. McGregor, J. Power Sources, 59 (1996) 31.

[5] OMI Acid Recirculation Process, www.OMI-NBE.com

[6] K. R. Bullock, B. K. Mahato and W. J. Wruck, J. Electrochem. Soc., Vol. 138, No. 12, December 1991

[7] MANUFACTURE OF POSITIVE PLATES FOR LEAD STORAGE BATTERIES Joseph A. Orsino, Mountain Lakes, N. J., assignor to National Lead Company, New York, N. Y., a corporation of New Jersey No Drawing. Application June 7, 1952

[8] US 5149606 A, method of treating battery electrode with per sulfate.

[9] A new pulse charging methodology for lead acid batteries J J A Wilkinson,1 BE (Hons), ME G A Covic, 2 BE (Hons), PhD, MIEEE, MIPENZ (Grad)

[10] US 4909955 A, Leadoxide paste mix for battery grids and method of preparation.

[11] Hydrogen peroxide by brightenyourfuture.com

[12] Chemical compounds by NEIL SCHLAGER, JAYNE WEISBLATT, ANDDAVID E. NEWTON, EDITORS Charles B. Montney, Project Editor.

[13] A novel cureless paste for positive plates in valveregulated batteries, J. Wang, S. Zhong, X.L. Wang*, H.K. Liu, S.X. Dou. Energy Storage Materials Research Group, ISEM, University of Wollongong, Wollongong, NSW 2522, Australia. Received 20 December 2002; accepted 17 February 2003 